\title{
ANALISIS REGRESI LINIER BERGANDA DALAM ESTIMASI PRODUKTIVITAS TANAMAN PADI DI KABUPATEN KARAWANG
}

\author{
Tesa Nur Padilah ${ }^{\text {1*, }}$, Riza Ibnu Adam ${ }^{2)}$ \\ ${ }^{1,2)}$ Program Studi Teknik Informatika, Fakultas Ilmu Komputer, Universitas Singaperbangsa \\ Karawang, Jl. H.S. Ronggowaluyo, Telukjambe Timur, Karawang, 41361 \\ "tesa.nurpadilah@staff.unsika.ac.id
}

\begin{abstract}
Abstrak
Karawang merupakan salah satu pusat penanaman padi di Pulau Jawa. Sebagai pusat penanaman padi, sudah seharusnya produktivitas padi dari tahun ke tahun mengalami peningkatan. Namun, produktivitas padi ternyata tidak konsisten, tahun 2015 mengalami kenaikan sedangkan tahun 2016 mengalami penurunan. Oleh karena itu, diperlukan suatu estimasi sehingga dapat diketahui produktivitas padi untuk tahun-tahun berikutnya. Beberapa algoritma yang dapat digunakan untuk mengestimasi hubungan antar variabel diantaranya regresi linier, fuzzy, dan jaringan syaraf tiruan. Regresi linier terbagi menjadi regresi linier sederhana dan regresi linier berganda. Regresi linier berganda digunakan untuk menelusuri pola hubungan antara variabel terikat dengan dua atau lebih variabel bebas. Berdasarkan suatu penelitian, regresi linier berganda lebih baik jika dibandingkan dengan metode fuzzy dan jaringan syaraf tiruan. Oleh karena itu, masalah produktivitas padi di Kabupaten Karawang dapat diestimasi dengan menggunakan analisis regresi linier berganda. Model regresi linier berganda dapat dinyatakan dalam bentuk perkalian matriks. Selanjutnya, perhitungan nilai-nilai koefisien regresi dapat dicari dengan menggunakan eliminasi Gauss. Berdasarkan model regresi yang didapat, sebesar 80,46\% faktor-faktor produktivitas padi dapat dijelaskan oleh produksi, luas panen, luas tanam, curah hujan, dan hari hujan. Sedangkan sisanya 19,54\% dapat dijelaskan oleh faktor-faktor lain yang tidak diteliti dalam penelitian ini. Variabel-variabel yang mempengaruhi peningkatan jumlah produktivitas yaitu variabel produksi dan curah hujan, sedangkan variabel-variabel yang mempengaruhi penurunan jumlah produktivitas yaitu variabel luas panen, luas tanam, dan hari hujan. Ratarata kesalahan relatif regresi yang diperoleh yaitu 0,04642 atau 4,642\%.
\end{abstract}

Kata Kunci: eliminasi gauss, estimasi, produktivitas, regresi linier berganda. 


\section{PENDAHULUAN}

Kabupaten Karawang mempunyai potensi besar dalam subsektor pertanian khususnya tanaman pangan baik ditinjau dari aspek sumber daya alam maupun sumber daya manusia. Sumber daya petani sangat menunjang keberhasilan pembangunan pertanian di Kabupaten Karawang, dimana $61,9 \%$ penduduk bergerak di bidang usaha pertanian dengan persentase buruh tani sekitar 59,43\% (Dinas Pertanian Kehutanan Perkebunan dan Peternakan Kabupaten Karawang, 2014). Menurut Makarim \& Suhartatik (2009), Karawang merupakan salah satu pusat penanaman padi di Pulau Jawa. Dengan luas areal pertanian lahan basah mencapai 97.000 hektar, Kabupaten Karawang mampu memproduksi padi sekitar 1,4 juta ton GKP per tahun. Dengan jumlah produksi padi sebesar itu, Karawang memberikan kontribusi beras hingga 9\% dari produksi beras yang dihasilkan provinsi Jawa Barat. Sebagai pusat penanaman padi, sudah seharusnya produktivitas padi dari tahun ke tahun mengalami peningkatan.

Namun, produktivitas padi ternyata tidak konsisten, pada tahun 2015 diketahui produktivitas mengalami kenaikan dari $76,05 \mathrm{kw} / \mathrm{ha}$ menjadi 79,99 kw/ha, sedangkan pada tahun 2016, produktivitas mengalami penurunan menjadi 75,38 $\mathrm{kw} / \mathrm{ha}$. Kenaikan dan penurunan ini dapat disebabkan oleh beberapa faktor seperti rata-rata curah hujan, luas tanam, produksi, luas panen, dan rata-rata hari hujan (Dinas Pertanian Kehutanan Perkebunan dan Peternakan Kabupaten Karawang, 2016). Hal tersebut dapat menimbulkan kekhawatiran jika suatu saat produktivitas mengalami penurunan secara terus menerus. Oleh karena itu, produktivitas $118^{\text {padi perlu diestimasi agar dapat }}$ diperkirakan seberapa besar produktivitas padi selanjutnya.

Beberapa algoritma yang dapat digunakan untuk mengestimasi hubungan antar variabel diantaranya regresi linier, fuzzy, dan jaringan syaraf tiruan. Regresi linier terbagi menjadi regresi linier sederhana dan regresi linier berganda. Regresi linier berganda merupakan suatu algoritma yang digunakan untuk menelusuri pola hubungan antara variabel terikat dengan dua atau lebih variabel bebas (Uyanik \& Guler, 2013). Pada penelitian Wati, Sebayang, \& Sitepu (2013) tentang peramalan jumlah produksi, regresi linier berganda lebih baik jika dibandingkan dengan fuzzy. Hal ini dapat dilihat dari nilai rata-rata kesalahan relatif regresi linier berganda sebesar 9,383\% yang lebih kecil daripada nilai rata-rata kesalahan relatif fuzzy sebesar $20.748 \%$. Selanjutnya, Nurmahaludin membandingkan algoritma Particle Swarm Optimization (PSO) pada jaringan syaraf tiruan dengan regresi linier berganda pada prakiraan cuaca. Hasil pengujian menunjukkan bahwa pada prakiraan temperatur udara minimum, penggunaan algoritma PSO memberikan tingkat kesalahan paling minimum dengan ratarata kesalahan sebesar 2,597\%, sedangkan pada regresi linier berganda sebesar $2,675 \%$. Akan tetapi, pada prakiraan temperatur udara maksimum, metode regresi linear berganda memberikan hasil yang lebih baik dengan rata-rata kesalahan sebesar $4.911 \%$, sedangkan pada jaringan syaraf tiruan sebesar 5,930\%.

Analisis regresi linier berganda telah digunakan dalam estimasi produktivitas padi di Kabupaten Demak oleh Aziz, Prasetyo, \& Sukmono (2018). Selain itu, pendugaan produktivitas padi dengan analisis regresi linier berganda juga telah 
dilakukan oleh Kurnianto, Ariffin, \& Azizah (2018) berdasarkan curah hujan di Kabupaten Malang. Oleh karena itu, pada penelitian ini digunakan regresi linier berganda untuk mengestimasi produktivitas padi di Kabupaten Karawang.

\section{METODE PENELITIAN}

Tahapan penelitian ini adalah sebagai berikut:

\section{Identifikasi Variabel}

Identifikasi variabel merupakan tahapan penentuan variabel terikat dan variabel-variabel bebas berdasarkan data yang diperoleh dari Dinas Pertanian Kehutanan Perkebunan dan Peternakan Kabupaten Karawang.

\section{Analisis Data}

Pada tahap ini dilakukan pengujian asumsi klasik dan pengujian hipotesis (Mona, Kekenusa, \& Prang, 2015). Pengujian dilakukan dengan bantuan tools Minitab 18 dan SPSS 16.

1. Pengujian Asumsi Klasik

Pengujian ini terdiri dari uji normalitas, uji multikolinieritas, uji heteroskedastisitas, dan uji autokorelasi. Syarat untuk mendapatkan model regresi yang baik adalah distribusi datanya normal atau mendekati normal. Jika data tidak berdistribusi normal, maka perlu dilakukan transformasi data terlebih dahulu. Selanjutnya, model regresi yang baik adalah model regresi yang tidak terjadi multikolinieritas, heteroskedastisitas, dan autokorelasi (Ndruru, Situmorang, \& Tarigan, 2014).

2. Pengujian Hipotesis

Setelah semua syarat untuk ditelitinya suatu model regresi terpenuhi semua, maka langkah selanjutnya untuk mengetahui diterima atau tidaknya hipotesis yang diajukan yaitu dengan melakukan uji simultan (uji F) dan uji signifikansi (uji $\mathrm{T}$ ). Uji $\mathrm{F}$ dilakukan untuk mengetahui apakah semua variabel bebas berpengaruh secara signifikan terhadap variabel terikat. Sedangkan uji $\mathrm{T}$ dilakukan untuk mengetahui apakah dalam model regresi, variabel bebas secara parsial berpengaruh signifikan terhadap variabel terikat (Sulistyono \& Sulistiyowati, 2017).

\section{Penentuan Model Regresi Linier Berganda}

Tahap selanjutnya adalah penentuan koefisien atau parameter-parameter regresi dengan metode kuadrat terkecil (Walpole, Myers, Myers, \& Ye, 2011). Pada metode kuadrat terkecil akan diperoleh suatu sistem persamaan linier yang dapat dibentuk ke dalam perkalian matriks. Perhitungan nilai koefisien regresi dilakukan dengan menyelesaikan solusi sistem. Solusi sistem tersebut dapat dicari dengan menggunakan eliminasi Gauss (Anton \& Rorres, 2005). Perhitungan dilakukan dengan bantuan tools Matlab 2016b. Selanjutnya hasil tersebut dibandingkan dengan nilai yang diperoleh dengan perhitungan menggunakan tools Minitab 18. Setelah itu, kebaikan model regresi dapat diukur dari nilai koefisien determinasi $\left(R^{2}\right)$ (Widiyawati \& Setiawan, 2015). Nilai koefisien determinasi berkisar antara 0 sampai 1 . Jika nilainya mendekati 1, maka dapat dikatakan pengaruh variabel bebas terhadap variabel terikat adalah besar. Artinya model yang digunakan baik untuk menjelaskan pengaruh variabel tersebut (Ndruru et al., 2014). 


\section{Evaluasi}

Evaluasi dilakukan dengan menghitung nilai rata-rata kesalahan relatif (error) (Wati et al., 2013).

\section{Penarikan Kesimpulan}

Dari hasil analisis yang didapatkan maka tahap terakhir yang dilakukan pada penelitian ini adalah penarikan kesimpulan.

\section{HASIL DAN PEMBAHASAN}

\section{Identifikasi Variabel}

Data yang digunakan adalah data perbulan yang berjumlah 57 data. Variabel terikat pada penelitian ini adalah produktivitas padi (kw/ha). Data produktivitas padi dihasilkan dari dua data utama yaitu data produksi dibagi dengan luas panen (Damiri \& Ishak, n.d.). Sedangkan variabel-variabel bebasnya yaitu produksi, luas panen, luas tanam, rata-rata curah hujan, dan rata-rata hari hujan.

\section{Analisis Data}

\section{Pengujian Asumsi Klasik}

1. Uji Normalitas

Uji normalitas menggunakan uji Kolmogorov-Smirnov (K-S) dengan bantuan tools Minitab 18. Hasil uji normalitas untuk data produksi dapat dilihat pada gambar berikut.

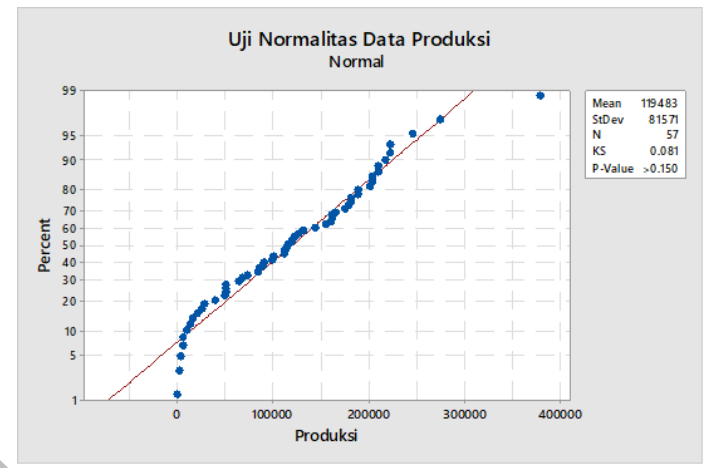

Gambar 1. Uji normalitas data produksi
Hasil uji normalitas untuk data luas panen dapat dilihat pada gambar berikut.

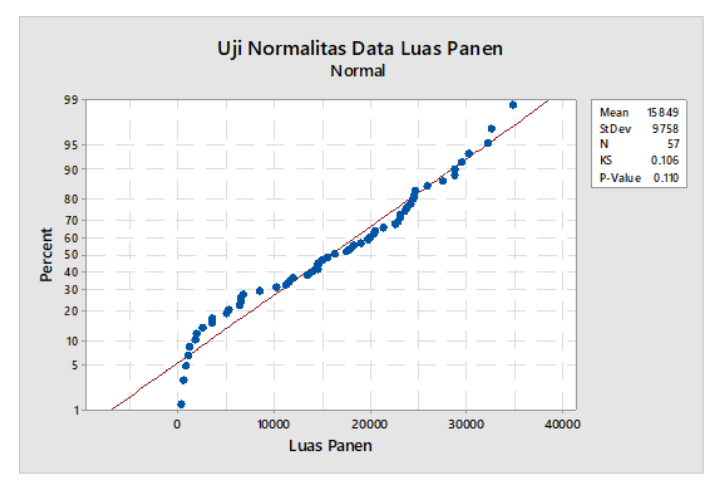

Gambar 2. Uji normalitas data luas panen

Hasil uji normalitas untuk data luas tanam dapat dilihat pada gambar berikut.

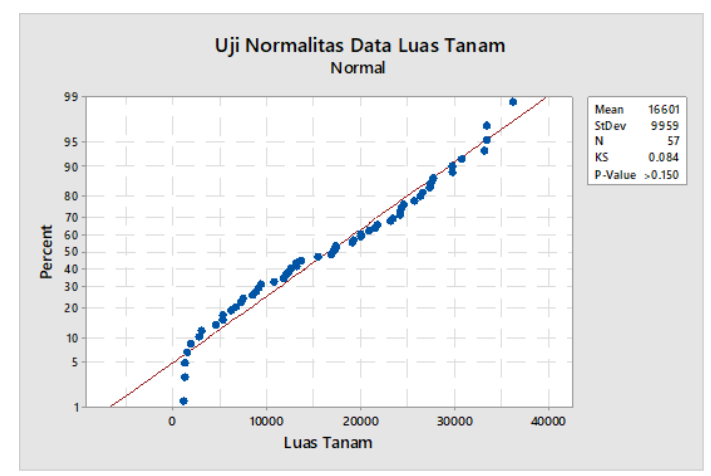

Gambar 3. Uji normalitas data luas tanam

Hasil uji normalitas untuk data ratarata curah hujan dapat dilihat pada gambar berikut.

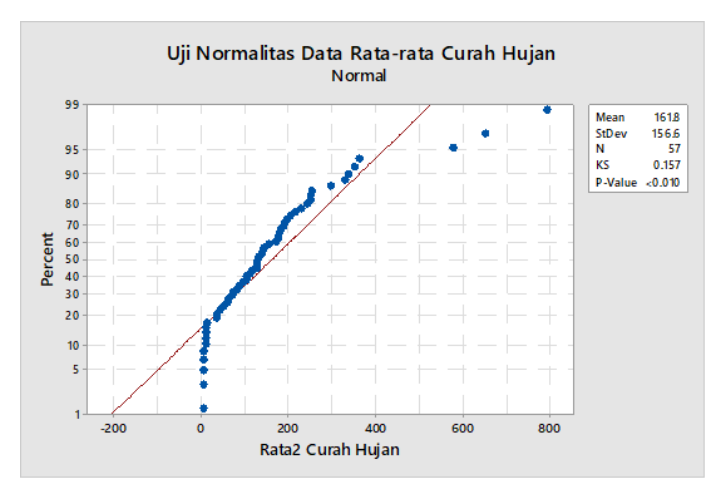

Gambar 4. Uji normalitas data rata-rata curah hujan 
Hasil uji normalitas untuk data ratarata hari hujan dapat dilihat pada gambar berikut.

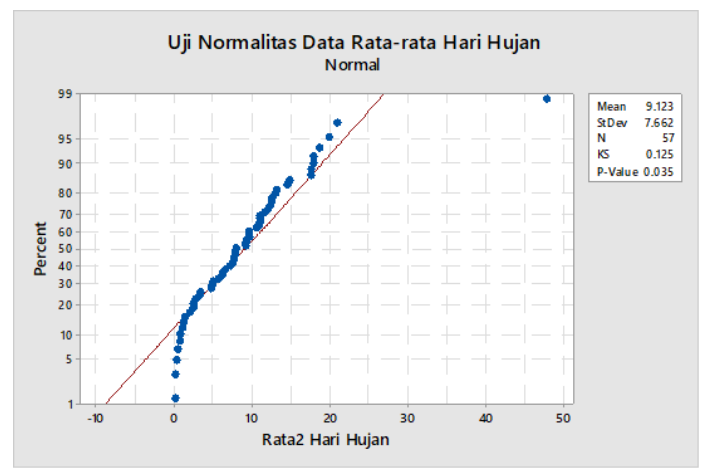

Gambar 5. Uji normalitas data ratarata hari hujan

Berdasarkan Gambar 1, 2, 3, 4, dan 5, nilai P-Value untuk data produksi, luas panen, luas tanam, ratarata curah hujan, dan rata-rata hari hujan masing-masing adalah >0,150; 0,110; >0,150; <0,010; dan 0,035. Data berdistribusi normal jika nilai P-Value lebih dari 0,05. Ini berarti variabel produksi, luas panen, dan luas tanam berdistribusi normal, sedangkan variabel rata-rata curah hujan dan ratarata hari hujan tidak berdistribusi normal.

Pada data yang tidak berdistribusi normal dilakukan transformasi Box-Cox. Kemudian pada data hasil transformasi tersebut dilakukan uji normalitas, hasilnya sebagai berikut.

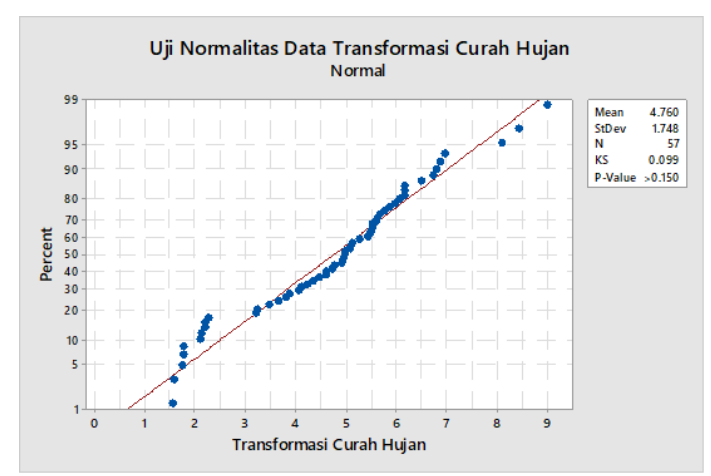

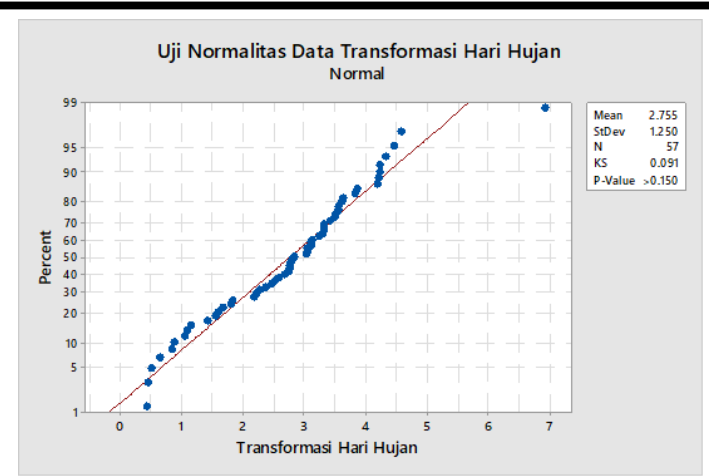

Gambar 6. Uji normalitas data hasil transformasi

Berdasarkan Gambar 6, P-Value untuk data transformasi curah hujan dan transformasi hari hujan keduanya bernilai >0,150. Ini berarti kedua variabel tersebut berdistribusi normal. Dengan demikian, data yang akan digunakan selanjutnya adalah variabel produksi, luas panen, luas tanam, transformasi curah hujan, dan transformasi hari hujan.

2. Uji Multikolinieritas

Pengujian ada tidaknya multikolinieritas dilakukan dengan melihat nilai VIF menggunakan tools Minitab 18 pada gambar berikut.

Coefficients

\begin{tabular}{lrrrrr} 
Term & Coef & SE Coef & T-Value & P-Value & VIF \\
\hline Constant & 82.48 & 5.55 & 14.87 & 0.000 & \\
Produksi & 0.000504 & 0.000035 & 14.45 & 0.000 & 7.13 \\
Luas Panen & -0.004074 & 0.000313 & -13.04 & 0.000 & 8.18 \\
Luas Tanam & -0.000084 & 0.000143 & -0.59 & 0.559 & 1.78 \\
Transformasi Curah Hujan & 1.11 & 1.71 & 0.65 & 0.518 & 7.82 \\
Transformasi Hari Hujan & -2.21 & 2.37 & -0.93 & 0.357 & 7.75
\end{tabular}

Gambar 7. Nilai coefficients

Berdasarkan Gambar 7 terlihat bahwa semua variabel bebas mempunyai nilai VIF kurang dari 10 , artinya tidak terjadi kasus multikolinieritas. 
3. Uji Heteroskedastisitas

Pengujian heteroskedastisitas dilakukan dengan uji Glejser menggunakan tools SPSS 16 sebagai berikut.

\section{Coefficients ${ }^{\mathrm{s}}$}

\begin{tabular}{|c|c|c|c|c|c|c|}
\hline \multirow[b]{2}{*}{ Made } & & \multicolumn{2}{|c|}{ Unstandardized Coefficients } & \multirow{2}{*}{$\begin{array}{c}\begin{array}{c}\text { Standardized } \\
\text { Coefficients }\end{array} \\
\text { Beta } \\
\end{array}$} & \multirow[b]{2}{*}{ t } & \multirow[b]{2}{*}{ Sig. } \\
\hline & & $\mathrm{B}$ & Std. Error & & & \\
\hline \multirow[t]{6}{*}{1} & (Constant) & 8.359 & 4.381 & & 1.908 & .062 \\
\hline & Produksi & $6.183 \mathrm{E}-5$ & .000 & .783 & 2.243 & .029 \\
\hline & Luas_Panen & .000 & .000 & -.941 & -2.516 & .015 \\
\hline & Luas_Tanam & $-9.496 \mathrm{E}-5$ & .000 & -.147 & .841 & .404 \\
\hline & $\begin{array}{l}\text { Transformasi_Curah_ } \\
\text { Hujan }\end{array}$ & 1.157 & 1.348 & .314 & .859 & .394 \\
\hline & $\begin{array}{l}\text { Transformasi_Hari_ } \\
\text { Hujan }\end{array}$ & -2.111 & 1.876 & -.409 & -1.125 & .266 \\
\hline
\end{tabular}

a. DependentVariable: Absui

\section{Gambar 8. Hasil uji glejser}

Berdasarkan Gambar 8, diperoleh nilai signifikansi untuk variabel produksi, luas panen, luas tanam, transformasi curah hujan, dan transformasi hari hujan masing-masing 0,$029 ; 0,015 ; 0,404 ; 0,394$; dan 0,266. Nilai-nilai tersebut lebih dari 0,01 sehingga tidak terdapat heteroskedastisitas dalam model. Ini berarti semua variabel bebas dalam model ini memiliki sebaran varian yang sama (homogen).

4. Uji Autokorelasi

Pengujian autokorelasi dilakukan dengan uji Durbin Watson (DW) menggunakan tools Minitab 18. Nilai statistik uji Durbin Watson diperoleh $d=1,93756$. Berdasarkan tabel Durbin Watson dengan derajat kepercayaan $\alpha=0,05$, banyaknya sampel $n=57$, dan banyaknya variabel bebas $k=5$ diperoleh nilai Durbin Lower $d L=1,3885$ dan Durbin Upper $d U=1,7675$. Oleh karena nilai $d$ lebih besar daripada $d U$ dan lebih kecil daripada $4-d U=$ 2,2325, atau

$$
\begin{gathered}
d U<d<4-d U \\
\Leftrightarrow 1,7675<1,93756<2,2325
\end{gathered}
$$

maka tidak terdapat autokorelasi positif dan negatif dalam model.

\section{Pengujian Hipotesis}

1. Uji Simultan (Uji F)

Hasil pengolahan data untuk uji $\mathrm{F}$ dengan tools SPSS 16 disajikan dalam tabel berikut.

\begin{tabular}{|c|c|c|c|c|c|}
\hline Model & $\begin{array}{l}\text { Sum of } \\
\text { Squares }\end{array}$ & df & $\begin{array}{l}\text { Mean } \\
\text { Square }\end{array}$ & $\mathrm{F}$ & Sig. \\
\hline $\begin{array}{c}1 \text { Regre } \\
\text { ssion }\end{array}$ & $\begin{array}{r}13364.2 \\
57\end{array}$ & & 2672.851 & $\begin{array}{r}41 . \\
990\end{array}$ & $.000^{\circ}$ \\
\hline $\begin{array}{l}\text { Resid } \\
\text { ual }\end{array}$ & $\begin{array}{r}3246.37 \\
4\end{array}$ & 51 & 63.654 & & \\
\hline Total & $\begin{array}{r}16610.6 \\
31\end{array}$ & 56 & & & \\
\hline
\end{tabular}

Tabel 1. Uji simultan (ujif) 
Hipotesis awal dan hipotesis alternatif pada uji F adalah:

$\mathrm{H}_{0}$ : variabel produksi, luas panen, luas tanam, transformasi curah hujan, dan transformasi hari hujan tidak mempunyai pengaruh yang signifikan secara bersama-sama terhadap variabel produktivitas.

$\mathrm{H}_{1}$ : variabel produksi, luas panen, luas tanam, transformasi curah hujan, dan transformasi hari hujan mempunyai pengaruh yang signifikan secara bersama-sama terhadap variabel produktivitas.

Berdasarkan Tabel 1, dapat diketahui bahwa nilai $F_{\text {hitung }}$ adalah 2672.851 dan $F_{\text {tabel }}$ dengan derajat kebebasan $(d f)$, untuk $d f_{1}=5$ dan $d f_{2}=51$ dan derajat kepercayaan $\alpha=0,05$ adalah 2,40. Dengan demikian, $\mathrm{F}_{\text {hitung }}>\mathrm{F}_{\text {tabel }}$ sehingga $\mathrm{H}_{0}$ ditolak, artinya variabel produksi, luas panen, luas tanam, transformasi curah hujan, dan transformasi hari hujan secara bersama-sama mempunyai pengaruh yang signifikan terhadap variabel produktivitas.

\section{Uji Signifikansi (Uji T)}

Hasil pengolahan data untuk uji T dengan tools Minitab 18 dapat dilihat dari nilai T-Value pada Gambar 7. Hipotesis awal dan hipotesis alternatif pada uji $\mathrm{T}$ adalah:

$\mathrm{H}_{0}$ : secara parsial tidak ada pengaruh signifikan variabel produksi, luas panen, luas tanam, transformasi curah hujan, atau transformasi hari hujan terhadap variabel produktivitas.

$\mathrm{H}_{1}$ : secara parsial terdapat pengaruh signifikan variabel produksi, luas panen, luas tanam, transformasi curah hujan, atau transformasi hari hujan terhadap variabel produktivitas.

Nilai $\mathrm{T}_{\text {tabel }}$ dengan
kebebasan $(d f) 51$ derajat
kepercayaan 0,05 untuk uji dua sisi
sehingga $\alpha=0,025$ adalah $2,00758$.
Dengan demikian, untuk:

a) Variabel Produksi

Berdasarkan Gambar 7 diperoleh nilai $\mathrm{T}$-Value $=14,45$ dan $\mathrm{P}$-Value $=0,000$ sehingga $\mathrm{T}$-Value $>\mathrm{T}_{\text {tabel }}$ $(14,45>2,00758)$ dan P-Value < 0,05 , artinya $\mathrm{H}_{0}$ ditolak. Dengan demikian, variabel produksi secara parsial berpengaruh signifikan terhadap variabel produktivitas.

b) Variabel Luas Panen

Berdasarkan Gambar 7 diperoleh nilai $\mathrm{T}$-Value $=-13,04$ dan $\mathrm{P}-$ Value $=0,000$ sehingga $\mathrm{T}-$ Value $<-\mathrm{T}_{\text {tabel }}$ $(-13,04<-2,00758)$ dan P-Value < 0,05 , artinya $\mathrm{H}_{0}$ ditolak. Dengan demikian, variabel luas panen secara parsial berpengaruh signifikan terhadap variabel produktivitas.

c) Variabel Luas Tanam

Berdasarkan Gambar 7 diperoleh nilai $\mathrm{T}$-Value $=-0,59$ dan $\mathrm{P}-$ Value $=0,559$ sehingga $\mathrm{T}-$ Value $>-\mathrm{T}_{\text {tabel }}$ $(-0,59>-2,00758)$ dan P-Value > 0,05 , artinya $\mathrm{H}_{0}$ diterima. Dengan demikian, variabel luas tanam secara parsial tidak berpengaruh signifikan terhadap variabel produktivitas.

d) Variabel Transformasi Curah Hujan Berdasarkan Gambar 7 diperoleh nilai $\mathrm{T}$-Value $=0,65$ dan $\mathrm{P}$-Value $=$ 0,518 sehingga $\mathrm{T}$-Value $<\mathrm{T}_{\text {tabel }}$ $(0,65<2,00758)$ dan $\mathrm{P}$-Value > 0,05 , artinya $\mathrm{H}_{0}$ diterima. Dengan demikian, variabel transformasi 
curah hujan secara parsial tidak berpengaruh signifikan terhadap variabel produktivitas.

e) Variabel Transformasi Hari Hujan Berdasarkan Gambar 7 diperoleh nilai $\mathrm{T}$-Value $=-0,93$ dan $\mathrm{P}$-Value $=0,357$ sehingga $\mathrm{T}$-Value $>-\mathrm{T}_{\text {tabel }}$ $(-0,93>-2,00758)$ dan P-Value > 0,05 , artinya $\mathrm{H}_{0}$ diterima. Dengan demikian, variabel transformasi hari hujan secara parsial tidak berpengaruh signifikan terhadap variabel produktivitas.

\section{Penentuan Model Regresi Linier Berganda}

Perhitungan nilai koefisien regresi $b_{0}, b_{1}, b_{2}, b_{3}, b_{4}$ dan $b_{5}$ dilakukan dengan menyelesaikan solusi sistem persamaan linier berikut.

$$
A \bar{x}=\bar{b}
$$

dengan

$$
A=\left[\begin{array}{cccccc}
57 & 6810549 & 903387 & 946267 & 271,30 & 157,01 \\
6810549 & 1186357108581 & 149211064216 & 87108935361 & 29826990,41 & 17159225,88 \\
903387 & 149211064216 & 19650294039 & 11535750561 & 3933443,88 & 2251150,88 \\
946267 & 87108935361 & 11535750561 & 21262964417 & 4876174,46 & 2877439,50 \\
271,30 & 29826990,41 & 3933443,88 & 4876174,46 & 1462,28 & 861,25 \\
157,01 & 17159225,88 & 2251150,88 & 2877439,50 & 861,25 & 520,01
\end{array}\right]
$$

$\overline{\boldsymbol{x}}=\left[\begin{array}{l}b_{0} \\ b_{1} \\ b_{2} \\ b_{3} \\ b_{4} \\ b_{5}\end{array}\right]$

$\bar{b}=\left[\begin{array}{c}4329,46 \\ 539835705,41 \\ 68105490 \\ 72241577,09 \\ 20701,12 \\ 11996,25\end{array}\right]$

Solusi persamaan (1) menggunakan eliminasi Gauss dengan bantuan tools Matlab 2016b diperoleh nilai berikut:

$$
\begin{gathered}
b_{0}=82,48 ; b_{1}=0,000504 ; \\
b_{2}=-0,004074 ; b_{3}=-0,000084 ; \\
b_{4}=1,11 ; b_{5}=-2,21
\end{gathered}
$$

sehingga diperoleh persamaan regresi linier berganda yaitu
Produktivitas $=82,48+0,000504$

Produksi - 0,004074 Luas Panen-

0,000084 Luas Tanam +1,11

Transformasi Curah Hujan - 2,21

Transformasi Hari Hujan

Hasil tersebut sama dengan hasil perhitungan dengan bantuan tools Minitab 18 pada gambar berikut. 
Regression Equation

Produktivitas $=82.48+0.000504$ Produksi -0.004074 Luas Panen -0.000084 +1.11 Transformasi Curah Hujan - 2.21 Transformasi Hari Huj

Gambar 9. Model regresi linier berganda

Persamaan regresi pada Gambar 9 dapat diartikan sebagai berikut:

1. Nilai koefisien untuk variabel produksi bernilai positif sebesar 0,000504 . Hal ini menunjukkan bahwa dengan mengasumsikan diabaikannya variabel bebas lainnya, jika variabel produksi meningkat sebesar $1 \%$ maka dapat mempengaruhi peningkatan jumlah produktivitas sebesar 0,000504 .

2. Nilai koefisien untuk variabel luas panen bernilai negatif sebesar 0,004074. Hal ini menunjukkan bahwa dengan mengasumsikan diabaikannya variabel bebas lainnya, jika variabel luas panen meningkat sebesar $1 \%$ maka dapat mempengaruhi penurunan jumlah produktivitas sebesar 0,004074.

3. Nilai koefisien untuk variabel luas tanam bernilai negatif sebesar 0,000084. Hal ini menunjukkan bahwa dengan mengasumsikan diabaikannya variabel bebas lainnya, jika variabel luas tanam meningkat sebesar $1 \%$ maka dapat mempengaruhi penurunan jumlah produktivitas sebesar 0,000084 .

4. Nilai koefisien untuk variabel transformasi curah hujan bernilai positif sebesar 1,11. Hal ini menunjukkan bahwa dengan mengasumsikan diabaikannya variabel bebas lainnya, jika variabel transformasi curah hujan meningkat sebesar $1 \%$ maka dapat mempengaruhi peningkatan jumlah produktivitas sebesar 1,11 .

5. Nilai koefisien untuk variabel transformasi hari hujan bernilai negatif sebesar -2,21. Hal ini menunjukkan

\begin{abstract}
bahwa dengan mengasumsikan diabaikannya variabel bebas lainnya, jika variabel transformasi hari hujan meningkat sebesar $1 \%$ maka dapat mempengaruhi penurunan jumlah produktivitas sebesar 2,21.
\end{abstract}

Dengan demikian, variabel-variabel yang mempengaruhi peningkatan jumlah produktivitas yaitu variabel produksi dan curah hujan, sedangkan variabel-variabel yang mempengaruhi penurunan jumlah produktivitas yaitu variabel luas panen, luas tanam, dan hari hujan.

Nilai koefisien determinasi $\left(R^{2}\right)$ dari persamaan regresi pada Gambar 5 dapat dilihat pada gambar berikut.

\section{Model Summary}

\begin{tabular}{rrrr} 
S & R-sq & R-sq(adj) & R-sq(pred) \\
\hline 7.97846 & $80.46 \%$ & $78.54 \%$ & $68.25 \%$
\end{tabular}

Gambar 10. Nilai koefisien determinasi

Berdasarkan Gambar 10, diperoleh nilai koefisien determinasi adalah $80,46 \%$, artinya sebesar $80,46 \%$ faktor-faktor produktivitas padi dapat dijelaskan oleh produksi, luas panen, luas tanam, transformasi curah hujan, dan transformasi hari hujan. Sedangkan sisanya 19,54\% dapat dijelaskan oleh faktor-faktor lain yang tidak diteliti dalam penelitian ini.

\section{Evaluasi}

Jika masing-masing variabel produksi, luas panen, luas tanam, transformasi curah hujan, dan transformasi hari hujan dimasukkan ke dalam persamaan pada Gambar 9, maka diperoleh estimasi produktivitas padi pada tabel berikut. 
Tabel 2. Estimasi produktivitas padi

\begin{tabular}{|c|c|c|}
\hline $\begin{array}{l}\text { Produktivitas } \\
\text { (kw/ha) }\end{array}$ & $\begin{array}{c}\text { Estimasi } \\
\text { Produktivitas } \\
\text { (kw/ha) }\end{array}$ & $\begin{array}{c}\text { Kesalahan } \\
\text { Relatif }\end{array}$ \\
\hline 60,45454545 & 76,67245907 & 0,26826624 \\
\hline 61,16564968 & 68,93625235 & \\
\hline 68,69033413 & 65,69505135 & \\
\hline & 139,5700058 & 0,200476954 \\
\hline 47,34344565 & 40,66201206 & 0,141126897 \\
\hline 140,1493931 & 101,6925244 & 439911 \\
\hline & 75,9759457 & \\
\hline 61,82746099 & 62,05998 & \\
\hline 0 & 10,35852338 & 0 \\
\hline 53,65478441 & 51,721 & 0,036038257 \\
\hline & 83,48761065 & \\
\hline 103,0324544 & 84,231 & 0,1 \\
\hline & 77,9290 & \\
\hline & 76,71594 & \\
\hline 75,20626368 & 74,81795475 & 253 \\
\hline & 86,55 & \\
\hline & 60,27 & \\
\hline $68,1^{\prime}$ & 71,586 & \\
\hline & 78,723 & \\
\hline & 77,90 & \\
\hline 72,772 & 76,20 & \\
\hline & 78,68 & \\
\hline 77,5 & 76,285 & 3179 \\
\hline 79,1 & 78,867 & \\
\hline 79,3 & 79,83 & 166 \\
\hline 57045 & 81,329 & 1624 \\
\hline & 72,31 & \\
\hline & 72,86 & 014 \\
\hline 76,02013247 & 74,33465417 & 0,022171473 \\
\hline & 74,31372465 & 0,027572948 \\
\hline 74,02 & 76,38 & 505 \\
\hline 76,938832 & 75,99424716 & 0,012277088 \\
\hline 78,62437077 & 78,11368064 & 0,006495316 \\
\hline 80,2667378 & 81,3385099 & 352631 \\
\hline 73,78396096 & 71,44116329 & 0,031752127 \\
\hline 77,64129269 & 77,76509277 & 0,001594513 \\
\hline 74,9132948 & 77,51871492 & 0,034779142 \\
\hline 70,16465423 & 79,0325661 & 0,126387167 \\
\hline 71,91062403 & 71,28957311 & 0,008636428 \\
\hline 77,48700415 & 76,19303735 & 0,016699146 \\
\hline
\end{tabular}

\begin{tabular}{ccc}
\hline $\begin{array}{c}\text { Produktivitas } \\
(\mathrm{kw} / \mathrm{ha})\end{array}$ & $\begin{array}{c}\text { Estimasi } \\
\text { Produktivitas } \\
\text { (kw/ha) }\end{array}$ & $\begin{array}{c}\text { Kesalahan } \\
\text { Relatif }\end{array}$ \\
\hline 75,48187322 & 71,27566172 & 0,05572479 \\
\hline 77,03693495 & 78,28622568 & 0,016216776 \\
\hline 76,79296346 & 80,26774954 & 0,045248756 \\
\hline 114,7587393 & 109,9638655 & 0,04178221 \\
\hline 80,04011768 & 82,12019434 & 0,025987926 \\
\hline 81,9900295 & 84,11745927 & 0,02594742 \\
\hline 80,97911833 & 82,42906923 & 0,017905244 \\
\hline 62,26787182 & 67,70460636 & 0,087312034 \\
\hline 78,78838174 & 78,11248054 & 0,008578691 \\
\hline 76,40870617 & 78,47077485 & 0,026987353 \\
\hline 76,00047136 & 76,31715479 & 0,004166861 \\
\hline 77,09120013 & 76,38781955 & 0,009124006 \\
\hline 76,54638755 & 75,00880613 & 0,020086923 \\
\hline 75,14425361 & 70,95420143 & 0,055760115 \\
\hline 74,58220797 & 76,27300776 & 0,022670283 \\
\hline 75,00818087 & 72,54490382 & 0,032840112 \\
\hline 76,12150453 & 73,55476976 & 0,033718918 \\
\hline Jumlah & 2,64588948 \\
\hline & &
\end{tabular}

Berdasarkan Tabel 2 diperoleh ratarata kesalahan relatif regresi yaitu

$$
\frac{2,64588948}{57}=0,04642
$$

atau $4,642 \%$.

\section{SIMPULAN}

Berdasarkan model regresi yang didapat, sebesar $80,46 \%$ faktor-faktor produktivitas padi dapat dijelaskan oleh produksi, luas panen, luas tanam, curah hujan, dan hari hujan. Sedangkan sisanya $19,54 \%$ dapat dijelaskan oleh faktor-faktor lain yang tidak diteliti dalam penelitian ini. Variabel-variabel yang mempengaruhi peningkatan jumlah produktivitas padi yaitu variabel produksi dan curah hujan, sedangkan variabel-variabel yang mempengaruhi penurunan jumlah produktivitas yaitu variabel luas panen, luas tanam, dan hari hujan. Rata-rata 
Tesa Nur Padilah dan Riza Ibnu Adam: Analisis Regresi Linier Berganda Dalam Estimasi Produktivitas Tanaman Padi di Kabupaten Karawang.

FIBONACCI : Jurnal Pendidikan Matematika dan Matematika. Vol. 5 (2), pp: 117 - 128.

kesalahan relatif regresi yang diperoleh yaitu 0,04642 atau $4,642 \%$.

\section{UCAPAN TERIMA KASIH}

Penulis mengucapkan terima kasih kepada Universitas Singaperbangsa Karawang sebagai penyandang dana dalam penelitian ini.

\section{DAFTAR PUSTAKA}

Anton, H., \& Rorres, C. 2005. Elementary Linear Algebra (9 $9^{\text {th }}$ ed.). New York: John Wiley and Sons.

Aziz, K.W., Prasetyo, Y., \& Sukmono, D. 2018. "Analisis regresi linier terhadap pola histogram spektral algoritma ndvi, evi, dan lswi untuk mengestimasi tingkat produktivitas padi (studi kasus: kabupaten demak, jawa tengah)". Jurnal Geodesi Undip. Vol. 7 (1), pp: 172181.

Damiri, A., \& Ishak, A. n.d. Perbandingan Produktivitas Padi Sawah dengan Beberapa Model Plot Ubinan pada Sistem Tanam Legowo 4:1. [Online] Tersedia: http://bengkulu.litbang.pertanian.go .id/ind/images/dokumen/publikasi/ Makalah_Ubinan.pdf [21 Agustus 2018].

Dinas Pertanian Kehutanan Perkebunan dan Peternakan Kabupaten Karawang. 2014. Laporan tahunan tahun 2014. Karawang: Penulis.

2016. Laporan tahunan tahun 2016. Karawang: Penulis.

Kurnianto, M. I., Ariffin, \& Azizah, N. 2018. "Pendugaan produktivitas padi (oryza sativa) berdasarkan curah hujan di kabupaten malang". Jurnal Produksi Tanaman, Vol. 6 (8), pp: 1859-1867.
Makarim, A. K., \& Suhartatik, E. 2009. Morfologi dan Fisiologi Tanaman Padi. [Online] Tersedia: http://www.litbang.pertanian.go.id/ special/padi/bbpadi_2009_itkp_11. pdf [21 September 2018].

Mona, M. G., Kekenusa, J. S., \& Prang, J. D. 2015. "Penggunaan regresi linear berganda untuk menganalisis pendapatan petani kelapa, studi kasus: petani kelapa di desa beo, kecamatan beo, kabupaten talaud". JdC. Vol. 4 (2), pp: 196-203.

Ndruru, R. E., Situmorang, M., \& Tarigan, G. 2014. "Analisa faktor-faktor yang mempengaruhi hasil produksi padi di deli serdang". Saintia Matematika. Vol. 2 (1), pp: 71-83.

Nurmahaludin. 2014. "Analisis perbandingan metode jaringan syaraf tiruan dan regresi linear berganda pada prakiraan cuaca”. Intekna. Vol. 14 (2), pp: 102-109.

Sulistyono \& Sulistiyowati, W. 2017. "Peramalan produksi dengan metode regresi linier berganda". Prozima. Vol. 1 (2), pp: 82-89.

Uyanik, G. K., \& Guler, N. 2013. “A study on multiple linear regression analysis". Procedia-Social and Behavioral Science. Vol. 106, pp: 234-240.

Walpole, R. E., Myers, R. H., Myers, S. L., \& Ye, K. 2011. Probability \& Statistics for Engineers \& Scientists ( $9^{\text {th }}$ ed.). USA: Prentice Hall.

Wati, S. E., Sebayang, D., \& Sitepu, R. 2013. "Perbandingan metode fuzzy dengan regresi linier berganda dalam peramalan jumlah produksi”. Saintia Matematika. Vol. 1 (3), pp: 273-284. 
FIBONACCI : Jurnal Pendidikan Matematika dan Matematika

Volume 5 No. 2 Bulan Desember Tahun 2019

Widiyawati \& Setiawan. 2015. "Analisis

faktor-faktor yang mempengaruhi tingkat produksi padi dan jagung di kabupaten lamongan". Jurnal Sains dan Seni ITS. Vol. 4 (1), pp: 103108. 